\title{
Pengaruh Gaya Mengajar dan Koordinasi Mata-Tangan terhadap Keterampilan Dasar Forehand Tenis
}

\author{
${ }^{1 *}$ Maulidin, ${ }^{1}$ Herman Syah, ${ }^{1}$ Intan Primayanti
}

\begin{abstract}
1Program Studi Pendididkan Olahraga dan Kesehatan, Universitas Pendidikan Mandalika, Jl.Pemuda
\end{abstract} No. 59A, Mataram, Indonesia 83125

*Corresponding Author e-mail: maulidin@ikipmataraml.ac.id

Received: April 2020; Revised: June 2020; Published: July 2020

\begin{abstract}
Abstrak
Tujuan dari penelitian ini adalah untuk mengetahui pengaruh dari gaya mengajar komando dengan gaya inklusi dan koordinasi mata-tangan terhadap keterampilan dasar forehand tenis. Penelitian ini merupakan penelitian experimen dengan desain faktorial $2 \times 2$. Sampel terdiri dari 48 Mahasiswa putra program studi olahraga yang sesuai dengan kreterian mampu melakukan pukulan forehand, kemudian dilakukan tes Koordinasi mata-tangan, selanjutnya diurutkan berdasarkan skor tertinggi dan terendah diambil 27\% kelompok atas dan 27\% kelompok bawah, masing-masing dibagi menjadi empat kelompok, masing-masing terdiri dari 12 mahasiswa. Teknik analisis data menggunakan analisis varians dua jalur (ANOVA) dan dilanjutkan dengan uji Tukey pada tingkat signifikansi $a=$ 0.05 . Hasil penelitian ini menunjukkan bahwa (1) gaya komando memberikan pengaruh yang lebih besar dari pada gaya Inklusi, (2) terdapat interaksi antara gaya mengajar dan koordinasi mata-tangan, (3) pada koordinasi mata-tangan tinggi, gaya komando memberikan pengaruh yang lebih besar daripada gaya inklusi, dan (4) pada koordinasi mata-tangan rendah, tidak terjadi perbedaan pengaruh yang berarti antara gaya komando dengan gaya inklusi. Berdasarkan hasil penelitian dapat disimpulkan bahwa gaya mengajar dan koordinasi mata-tangan berpengatuh terhadap keterampilan forehand tenis lapangan.
\end{abstract}

Kata Kunci: Keterampilan Dasar Forehand Tenis, Koordinas Mata-Tangan, Komando, Inklusi

\section{The Effects of Teaching Style and Hand-Eye Coordination on Basic Forehand Tennis Skills}

\begin{abstract}
The purpose of this study was to determine the effect of command teaching style with inclusion style and eyehand coordination on the basic skills of tennis forehand. This research is an experimental research with a $2 \times 2$ factorial design. The sample consisted of 48 male students of sports studies programs that are in accordance with criteria capable of making a forehand, then conducted a hand-eye coordination test, then sorted by the highest and lowest scores taken $27 \%$ of the upper group and $27 \%$ of the lower group, each divided into four groups, each consisting of 12 students. Data analysis technique used two-way analysis of variance (ANOVA) and then followed by Tukey's test at the significance level $a=0.05$. The results of this study indicate that (1) the command style gives a greater influence than the Inclusion style, (2) there is an interaction between teaching style and eyehand coordination, (3) on high eye-hand coordination, the command style gives more influence greater than the inclusion style, and (4) in low hand-eye coordination, there is no significant difference in influence between the command style and the inclusion style. Based on the results of the study it can be concluded that the teaching style and eye-hand coordination are subject to field tennis forehand skills.
\end{abstract}

Keywords: Forehand Tennis Skills, Hand-Eye Coordination, Command, Inclusion

How to Cite: Maulidin, M., Syah, H., \& Primayanti, I. (2020). Pengaruh Gaya Mengajar dan Koordinasi Mata-Tangan terhadap Keterampilan Dasar Forehand Tenis. Jurnal Penelitian dan Pengkajian Ilmu Pendidikan: e-Saintika, 4(2), 126-133. doi:https://doi.org/10.36312/e-saintika.v4i2.199 


\section{PENDAHULUAN}

Tenis adalah permainan olahraga dinamis yang dimainkan dengan raket dan bola. Keberhasilan dalam bermain tenis ditentukan oleh beberapa faktor terlepas dari faktor sosial, kapasitas potensial dan pengalaman kompetisi semuanya dapat mempengaruhi keberhasilan (Filipcic \& Filipcic, 2005). Tenis juga merupakan salah satu olahraga yang membutuhkan keterampilan keseimbangan dan koordinasi, karakteristik seperti kekuatan, daya tahan, kecepatan dan fleksibilitas (Schöborn, 2000)

Dalam bermain tenis ada dua pukulan dasar yaitu forehand dan backhand. Kedua pukulan tersebut dapat dilakukan dengan urutan gerakan yang komplek dari aktivitas otot yang menggabungkan pola koordinasi yang halus dari otot trunkus ekstrimitas bawah (Mavvidis et al., 2005). Dari kedua teknik dasar pukulan dalam tenis, pukulan forehand yang lebih dominan digunakan. Hal ini sejalan dengan pendapat Brown (2001) yang menyatakan bahwa sedikit setengah dari seluruh pukulan tenis adalah forehand. Singer, et al. (1996) juga menyatakan bahwa forehand drive adalah jenis pukulan dengan raket digerakan ke belakang di samping badan, kemudian diayunkan ke depan untuk memukul bola. Jadi dapat disimpulkan bahwa forehand drive adalah pukulan yang dilakukan setelah bola memantul yang sejajar dengan net dan jatuh di backcourt lawan serta dilakukan dengan tangan terbuka.

Teknik pukulan forhand dalam tenis lapangan termasuk gerakan yang komplek, gabungan dari beberapa gerakan yang harus dilakukan secara terpadu dan selaras mulai dari sikap awalan, ayunan raket dan saat raket kontak dengan bola sehingga diperlukan koordinasi mata-tangan yang baik (Iino Y., \& Kajimo T., 2009). Menurut Sailer et al,. (2005) Koordinasi adalah pekerjaan kelompok otot yang harmonis selama kinerja motorik dan sebagai indikasi keterampilan. Selanjutnya Jannapureddy S. dkk, (2015) menyatakan bahwa gerakan koordinasi membutuhkan integrasi sistem sensorik dan motorik ke dalam pola yang sama dan harmonis.

Koordinasi mata-tangan dan posisi tubuh yang tepat adalah komponen penting dalam melakukan pukulan forehand pada tenis, tetapi perlu dibedakan pada tingkat kemahiran atlet terlatih dan tidak terlatih yang dapat mempengaruhi teknik pukulan (McPherson SL., 2002). Pukulan forehand diperlukan daya sejumlah sigmen tubuh harus dikoordinasikan sedemikian rupa sehingga kecepatan ayunan raket mempengaruhi kecepatan pukulan Elliott B. (2006). Tehnik pukulan pada tenis membutuhkan fundamental yang kuat. Para ahli tenis menyarankan untuk meminimalkan gerakan mata dan tangan dalam belakukan pukulan forehand sehingga menambah keefektifan pukulan Rodriguez, et al. (2002)

Penguasaan suatu keterampilan tidak dapat dicapai dengan mudah, tetapi diperlukan proses pembelajaran yang benar. Pembelajaran keterampilan merupakan proses untuk mempelajari atau menguasai tahapan gerakan yang trampil, dengan refleksi gerakan yang benar. Penguasaan keterampilan pada setiap cabang olahraga berlandaskan pada penguasaan keterampilan dasar. Ada tiga sistem yang dapat mewakili penggolongan keterampilan gerak yaitu: (a) stabilitas lingkungan (b) jelas tidaknya titik awal serta akhir dari gerakan, dan (c) ketepatan gerakan yang dimaksud (Mulyani \& Gracinia, 2007).

Beberapa gaya mengajar sering dilakukan antara lain yang mengajar dengan menggunakan gaya mengajar komando dan gaya inklusi. Gaya mengajar mengacu pada pembelajaran yang sering dilakukan dalam pendidikan pendidikan jasmani. 
Mosston dan Ashwort menghadirkan sebelas gaya mengajar yang sering dilakukan, sebagai berikut (1) Command Style (gaya perintah), (2). Gaya latihan, (3) Gaya repsiprokal (gaya resiprokal), (4) Gaya self-ceck, (5) Gaya inklusi, (6) Gaya penemuan terbimbing, (7) Gaya gaya confergent, (8) Gaya produksi yang berbeda, (9) Gaya program individual (gaya desain program-linier individual) (10) Pelajar memprakarsai gaya, dan (11) Gaya belajar mandiri (Mosston, 2008).

Gaya mengajar adalah penampilan dosen dalam melaksanakan pembelajaran sesuai dengan kemampuannya untuk mendorong siswa dalam upaya untuk mengeksploitasi keterampilan dalam teknik dasar forehand. Ini gaya mengajar dapat mempengaruhi suasana belajar yang pada akhirnya dapat mempengaruhi belajar siswa hasil di kampus. Beberapa gaya mengajar populer dan pengamatan penulis termasuk gaya komando dan gaya inklusi. Penelitian ini terbatas pada menguji pengaruh gaya mengajar komando dan gaya inklusi sebagai variabel bebas, serta koordinasi mata-tangan sebagai variabel moderat, terhadap hasil belajar keterampilan teknik dasar forehand tenis lapangan pada mahasiswa pria sebagai variabel terikat.

Gaya komando adalah gaya yang mengajar dengan respons langsung terhadap rangsangan (guru memberi contoh dan siswa melakukannya), bertujuan untuk mendapatkan penampilan yang cermat dengan mengikuti instruksi yang ada; (1) Semua keputusan dibuat oleh guru (2) Mengikuti instruksi dan melaksanakan tugas adalah kegiatan utama siswa (3) Menghasilkan tingkat aktivitas yang tinggi (4) Dapat membuat siswa merasa terlibat dan termotivasi (5) Mengembangkan disiplin ilmu perilaku, sebagaimana harus mematuhi prosedur yang telah ditetapkan. (Fitri Amalia, James Tangkudung \& Firmansyah Dlis, 2018). Dalam mengevaluasi tentang efektivitas proses pengajaran aktivitas fisik, Dudley, et al (2011) melihat bahwa metode pembelajaran langsung adalah strategi yang lebih efektif untuk meningkatkan efektivitas fisik anank-anak dan meningkatkan keterampilan gerak, Fanarioti (2014) juga menunjukkan bahwa metode langsung memberikan hasil yang lebih baik dalam pengembangan keterampilan gerakan peserta ujian dalam kasus anak-anak antara 12-14 tahun.

Gaya Mengajar komando dengan instruksi langsung sebagai model gaya mengajar, yang terkait langsung dengan teori pembelajaran konduktif dan model gaya mengajar yang paling umum digunakan dalam teknik mengajar dan keterampilan motoric (Maria Cuellar, M., (2016)

Dalam gaya mengajar yang diaktifkan siswa, siswa membuat banyak keputusan. Secara khusus, dalam gaya inklusi, guru memutuskan konten dari apa yang akan diajarkan, namun hal itu memungkinkan siswa memilih tingkat kesulitan dan memeriksa pekerjaan mereka sendiri terhadap kriteria yang disiapkan oleh guru (Mosston, M. \& Ashworth, S., 2002). Gaya mengajar ini memfasilitasi kesempatan yang sama pada peserta didik terlepas dari jenis kelamin, kemampuan fisik atau kognitif karena siswa memiliki kemampuan keterampilan yang berneda-beda (Byra, M, 2006). Peneliti menemukan bahwa gaya inklusi efektif dalam meningkatkan keterampilan, terutama untuk siswa dengan tingkat keterampilan rata-rata (Beckett, K., 1991., Goldberger, M., \& Gerney, P., 1986).

Tujuan dari penelitian ini adalah untuk menguji bagai mana metode mengajar gaya komando dengan gaya inklusi dan koordinasi mata-tangan dapat meningkatkan keterampilan teknik dasar forehand tenis lapangan mahasisiswa. Penelitian serupa yang pernah dilakukan Fitri Amalia, dkk tahun 2018 dengan judul pengaruh gaya 
mengajar dan koordinasi terhadap hasil belajar keterampilan tenis meja. Penelitian ini menggunakan tiga gaya mengajar; gaya mengajar komando, gaya mengajar reciprocal dan gaya mengajar inklusi, desain penelitian menggunakan 2x3. Hasilnya menunjukkan ada perbedaan pengaruh gaya mengajar komando dengan gaya mengajar inklusif pada hasil belajar keterampilan tenis meja kepada siswa secara keseluruhan dan hasil analisis tukey bahwa terdapat perbedaan antara kelompok komando (A1B1) dan inklusi (A3B1) dengan koordinasi tinggi diperoleh nilai Mean Difference sebesar 9,40 dan signifikansi sama dengan 0,02. Karena nilai signifikansi lebih kecil dari a = 0,05 $(0,02<0,05)$, artinya H0 ditolak, dengan kata lain ada perbedaan hasil belajar keterampilan tenis meja di antara mereka yang mengikuti gaya mengajar komando dengan gaya mengajar inklusi pada siswa yang memiliki koordinasi tinggi.

Penelitian yang peneliti lakukan membandingkan dua gaya mengajar yaitu gaya komando dan gaya inklusi dengan menggunakan desai 2x2 menunjukkan hasil yang hampir sama dimana gaya komando memberikan pengaruh lebih besar dibandingkan dengan gaya inklusi terhadap hasil keterampilan teknik dasar forehand permaina tenis lapangan mahasiswa.

\section{METODE}

Penelitian ini adalah penelitian experimen dengan desain penelitian treatment by level 2 × 2, dimana masing-masing variabel bebas diklasifikasikan menjadi 2 (dua). Variabel bebas perlakuan diklasifikasikan dalam dua bentuk gaya mengajar (A) yaitu dengan gaya mengajar komando $\left(\mathrm{A}_{1}\right)$ gaya mengajar inklusi $\left(\mathrm{A}_{2}\right)$. Sedangkan vaiabel bebas moderator diklasifikasikan dalam dua tingkatan koordinasi mata-tangan (B) yaitu koordinasi mata-tangan tinggi $\left(B_{1}\right)$ dan koordinasi mata-tangan rendah $\left(B_{2}\right)$ yang secara ringkas disajikan pada Tabel 1.

Tabel 1. Pengelompokan sampel berdasarkan tinggi dan rendah hasil tes koordinasi mata-tangan.

\begin{tabular}{lcc}
\hline Gaya Mengajar (A) & $\begin{array}{c}\text { Gaya Komando } \\
(\mathrm{A} 1)\end{array}$ & $\begin{array}{c}\text { Gaya Inklusi } \\
(\mathrm{A} 2)\end{array}$ \\
Koordinasi (B) & 12 & 12 \\
Tinggi (B1) & 12 & 12 \\
Rendah (B2) & & \\
\hline
\end{tabular}

Sebelum dibagi sampel melakukan tes koordinasi mata-tangan dengan melempar tangkap bola kedinding, 10 bola dilempar kanan tangkap kanan dan 10 bola dilempar bola dengan tangan kanan tangkap tangan kiri (Ismayati, 2006). Kemudian dibagi dengan metode Frank M.Verduci (1980), yaitu 27\% kelompok mahasiswa yang memiliki kemampuan motorik tinggi, dan 27\% kelompok mahasiswa yang memiliki kemampuan motorik rendah. Sampel yang digunakan dalam penelitian ini sebanyak 48 mahasiswa yang berpartisipasi mengikuti latihan dan di bagi menjadi 4 kelompok masing-masing terdiri dari 12 orang. Sebelum dah sesudah perlakuan keterampilan forehandn siswa diukur dengan melakukan pukula forehand sebanyak 15 bola melewati bawah tali yang direntangkan di atas net dengan ketinggian 7 kaki dan diarahkan ke daerah-daerah yang telah digariskan yang berukuran 41/2 kaki dibelakang daerah line service, dan dilenkapi dengan angka mulai dari 5, 4, 3 dan 2 disetiap kotaknya. Analisis data menggunakan teknik anava dua 
jalur, dengan taraf kepercayaan $a=0,05$. Sebelum data diolah menggunakan teknik analisis varians, terlebih dahulu dilakukan uji persyaratan anava, yaitu uji normalitas menggunakan uji lilliefors dan uji homogenitas varians menggunakan uji Bartlet dengan taraf signifikansi $\alpha=0.05$.

\section{HASIL DAN PEMBAHASAN}

Data pada Tabel 2 merupakan hasil belajar keterampilan forehand tenis dengan penerapan metode mengajar gaya komando dengan gaya inklusi dan mempertimbangkan tinggi rendahnya kemampuan koordinasi mata-tangan siswa.

Tabel 2. Rangkuman Hasil Anava Dua Jalur Terhadap Data Keterampilan Forehand tenis

\begin{tabular}{|c|c|c|c|c|c|}
\hline Sumber Varians & JK & Dk & $\mathrm{RJK}=\frac{J K}{d k}$ & $\mathrm{Fo}=\frac{R J K}{R J K D}$ & $\begin{array}{c}\text { Ftabel } \\
(\alpha=0.05)\end{array}$ \\
\hline $\begin{array}{l}\text { Antar Gaya } \\
\text { Mengajar (A) }\end{array}$ & 146.68 & 1 & 146.68 & 4.51 & 4.06 \\
\hline $\begin{array}{l}\text { Koordinasi Mata- } \\
\text { Tangan (B) }\end{array}$ & 13.26 & 1 & 13.26 & 0.41 & 4.06 \\
\hline Interaksi $(\mathrm{A} \times \mathrm{B})$ & 301.07 & 1 & 301.07 & 9.25 & 4.06 \\
\hline Dalam Kelompok & 1432.50 & 47 & 32.55 & - & - \\
\hline Total Direduksi & 461.00 & 48 & - & - & - \\
\hline
\end{tabular}

Dengan dibuktikannya hipotesis penelitian yang menyatakan bahwa terdapat pengaruh interaksi antara gaya mengajar dan Koordinasi Mata-Tangan terhadap peningkatan keterampilan dasar forehand tenis, maka analisis perlu dilanjutkan dengan uji Tuckey seperti disajikan Tabel 3.

Tabel 3. Hasil Anava Tahap Lanjut Dengan Uji Tuckey

\begin{tabular}{lcccc}
\hline $\begin{array}{l}\text { Kelompok Yang } \\
\text { Dibandingkan }\end{array}$ & Dk & Qh & Qt $=0.05$ & Keterangan \\
\hline $\mathrm{A}_{1}$ dan $\mathrm{A}_{2}$ & 2.24 & 3.00 & 2.97 & Signifikan \\
$\mathrm{A}_{1} \mathrm{~B}_{1}$ dan $\mathrm{A}_{2} \mathrm{~B}_{1}$ & 4.48 & 5.16 & 3.77 & Signifikan \\
$\mathrm{A}_{1} \mathrm{~B}_{2}$ dan $\mathrm{A}_{2} \mathrm{~B}_{2}$ & 4.48 & 0.92 & 3.77 & Tidak Signifikan \\
\hline
\end{tabular}

Berdasarkan analisis varian (ANOVA) Hasil pengujian menunjukkan bahwa secara keseluruhan, skor gaya mengajar pada kelompok yang diberikan gaya komando lebih tinggi pengaruhnya dari pada kelompok yang diberi gaya mengajar inklusi. Dari hasil temuan ini dapat dikemukakan bahwa latihan yang diberikan dengan gaya komando hasilnya lebih efektif dibandingkan dengan pembelajaran yang diberikan dengan gaya Inklusi.

Hasil temuan ini dapat dikemukakan bahwa gaya komando akan menjadi efektif dalam meningkatkan keterampilan Forehand tenis karena gaya komando membuat siswa lebih mandiri dalam latihan sehingga dapat meningkatkan kreativitas siswa. hal ini sesuai dengan pendapat Moston (2008) Mengajar gaya komando memberikan siswa untuk berlatih secara individu dan mandiri, serta menyediakan waktu guru untuk memberikan umpan balik kepada siswa secara individu dan pribadi". Gaya Inklusi $\left(\mathrm{A}_{2}\right)$ diterima. rerata skor gaya latihan $\left(\mathrm{A}_{1}\right)=58.52$, lebih tinggi secara signifikan dari rerata skor gaya inklusi $\left(\mathrm{A}_{2}\right) 55.02(\mathrm{Qh}=3.00>\mathrm{Qt}=2.97)$, 
Temuan ini sejalan dengan hasil penelitian yang dilakukan Syahruddin (2016) pada gaya mengajar komando lebih berpengaruh terhadap peningkatan keterampilan passing atas bola voli dimana nilia t-hutung11.084. Karena tingkat probabilitas 0.000 lebih kecil daripada a 0.05, maka data passing atas bolavoli dengan uji beda adalah ada pengaruh gaya mengajar komando yang signifikan $(\mathrm{p}<0.05)$, pada penelitian ini tidak membedakan tingkat keterampilan yang dimiliki siswa.

Athin et al. (2015) Gaya mengajar (Komando) adalah metode yang paling berpusat pada guru dan banyak digunakan dalam pengajaran pendidikan jasmani. Ini menargetkan belajar suatu kegiatan dengan akurasi, sesegera mungkin di bawah arahan guru. Dalam belajar olahraga dan terlibat dalam evaluasi diri sesuai dengan kriteria yang ditetapkan oleh guru, sementara bertanggung jawab untuk menilai gerakan yang benar atau salah sendiri (Mosston \& Ashworth 2002). Dengan demikian, tanggung jawab pribadi mereka untuk evaluasi kinerja mereka sangat penting untuk metode ini untuk menghasilkan prestasi, tetapi juga menimbulkan tantangan bagi mereka karena merupakan cara belajar yang berbeda dari kebiasaan mereka (Byra, 2006a). Dengan gaya komando maka siswa akan lebih mudah untuk menguasai teknik dalam permainan tenis serta lebih mudah geraknya, oleh sebab itu gaya latihan memberikan pengaruh yang lebih besar terhadap peningkatan Keterampilan Forehand tenis. Jika di analisis secara bersamaan gaya komando dan gaya inkuiri keduanya memberikan pengaruh terhadap peningkatan keterampilan dasar Forehand, atau dengan kata lain pengaruh gaya mengajar terhadap peningkatan keterampilan Forehand tenis tergantung dari koordinasi mata-tangan. Hasil perhitungan menunjukkan bahwa $F_{\text {hitung }}=9.25>\mathrm{F}_{\text {tabel }}=4.06$.

Jika dilihat dari tingkat koordinasi mata-tangan yang tinggi metode mengajar gaya komando memberikan pengaruh lebih besar terhadap peningkatan keterampilan forehand dibandingkan dengan gaya inklusi. rerata skor gaya komando $\left(\mathrm{A}_{1} \mathrm{~B}_{1}\right)=60.49$ secara signifikan lebih tinggi dari rerata skor gaya mengajar inklusi $\left(\mathrm{A}_{2} \mathrm{~B}_{1}\right)=51.99(\mathrm{Qh}=5.16>\mathrm{Qt}$ 3.77). temuan ini didukung oleh hasil penelitian yang dilakukan oleh Safari, dkk (2017) menyatakan bahwa kelompok koordinasi yang tinggi memiliki lebih banyak peran terhadap hasil topspin tenis meja. Tetapi pada koordinasi mata-tangan kategori rendah tidak berbeda secara signifikan, jadi dapat diartikan latihan pada koordinasi mata-tangan rendah setelah diberikannya perlakuan dari dua gaya mengajar terjadi peningkatan keterampilan Forehand tenis siswa, akan tetapi peningkatan yang terjadi setelah perlakuan tersebut tidak terjadi perbedaan yang nyata (signifikan), dimana diperoleh skor keterampilan Forehand tenis anggota kelompok $\mathrm{A}_{2} \mathrm{~B}_{2}=58.05$ tidak berbeda secara signifikan dengan rata-rata skor peningkatan keterampilan Forehand tenis anggota kelompok $\mathrm{A}_{1} \mathrm{~B}_{2}=56.54\left(\mathrm{Q}_{\mathrm{h}}=\right.$ $\left.0.92<Q_{t}=3.77\right)$.

\section{KESIMPULAN}

Penelitian ini dapat di simpulkan bahwa kedua metode pembelajaran dapat meningkatkan keterampilan forehan tenis, tetapi mengajar gaya komando memberikan pengaruh lebih besar terhadap keterampilan siswa yang memiliki tingkat koordinasi mata-tangan yang tinggi dan gaya inklusi memberikan pengaruh lebih besar terhadap mahasiswa yang memiliki tingkat koordinasi mata-tangan rendah. 


\section{SARAN}

Gaya mengajar setiap guru mempunyai ciri khas masing masing, tetapi perlu memperhatikan karakter dan kemampuan siswa. Mengajar gaya komando merupakan gaya yang pelu diterapkan bagi guru yang mengajarkan mata kuliah teori dan praktik dilapangan, ini berdasarkan hasil temuan peneliti

\section{UCAPAN TERIMA KASIH}

Dekan Fakultas Ilmu Keolahragaan dan Kesehatan Masyarakat, Mahasiswa yang telah bersedia meluangkan waktu selama penelitian.

\section{DAFTAR PUSTAKA}

Athin P., Nikolaos D., Athanasios P., (2015) The effects of reciprocal and self-check teaching styles in students' intrinsic-extrinsic motivation, enjoyment and autonomy in teaching traditional Greek dances. Journal of Physical Education and Sport. (JPES), 15(2), Art 53, pp. 352 - 361, DOI:10.7752/jpes.2015.02053

Beckett, K. (1991) The effects of two teaching styles on college students' achievement of selected physical education outcomes. Journal of Teaching in Physical Education, 10, 153-169.

Byra, M. (2006) Teaching styles and inclusive pedagogies. In Handbook of research in physical education, D. Kirk, M.O'Sullivan, \& D. Macdonald (Eds.), SAGE Publications: London, pp.449-466.

Dudley, D., Okely, A., Pearson, P. and Cotton, W. (2011). A systematic review of the effectiveness of physical education and school sport interventions targeting physical activity, movement skills and enjoyment of physical activity. European Physical Education Review, 17(3), 353-378. doi: 10.1177/1356336X1141673

Elliott B. (2006) Biomechanics and tennis. Journal Sports Med; 40: 3926.

Fanarioti, M. (2014). The influence of direct and indirect teaching method in the development of selected technical skills in the sport of football to children aged 12-14 years old. Journal of Physical Education and Sport, 14(3), 413-420. doi: 10.7752/jpes.2014.03063

Fitri Amalia, James Tangkudung dan Firmansyah Dlis (2018) The Effect of Teaching Styles and Coordination to the Learning Resul of Table Tenis. Journal of Indonesian Physical Education and Sport. 4 (1) 35-45 http://journal.unj.ac.id/unj/index.php/jipes

Filipcic A, Filipcic T. The relationship of tennis-specific motor abilities and the competition efficiency of young female tennis players. Kinesiology 2005; 372: 167-72.

Goldberger, M., \& Gerney, P. The effects of direct teaching styles on motor skill acquisition of fifth grade children. Research Quarterly for Exercise and Sport, (1986), 57, 215-219.

Goldberger, M., Gerney, P., \& Chamberlain, J. The effects of three styles of teaching on the psychomotor performance of fifth grade children. Research Quarterly for Exercise and Sport, (1982), 53, 116-124.

Iino Y, Kojima T. Kinematics of table tennis topspin forehands: effects of performance level and ball spin. J Sports Sci 2009;27:1311-21. http:/ / bit.ly/1D9uenA

Ismaryati. (2006). Tes dan Pengukuran Olahraga. Surakarta: Sebelas Maret University Press

Jannapureddy S. 2015. Timing Differences in Eye-Hand Coordination Between Experienced and Inexperienced Tennis Players. 
https://www.researchgate.net/publication/275155619

Maria Cuellar-Moreno. (2016). Effects of the command and mixed styles on student learning in primary education. Journal of Physical Education and Sport. 16 (4) 11591169. DOI:10.7752/jpes.2016.04186

Magethi, B. (1990). Tenis Para Bintang. Bandung: Pioner Jaya.

Mavvidis A, Koronas K, Riaganas C, Metaxas T. (2005). Speed differences between forehand and backhand in intermediate-level tennis players. Kinesiology; 37(2): 159-63.

McPherson SL. (2000) Expert-novice differences in planning strategies during collegiate singles tennis competition. J Sport Exer Psych;22:39-62. http://bit.ly/1Cyy4E0

Mosston, M. \& Ashworth, S. (2002).Teaching Physical Education. (5th Ed), Benjamin Cummins: San Francisco CA,

Mosston ans Sara Asworth. (2008). Teaching Physical Education, (Online Edition), New York: MacMillan College Publising Company Inc.

Rodriguez ST, Vickers JN, Williams AM. (2002) Head, eye and arm coordination in table tennis. J Sports Sci;20:187-200. http:// bit.ly/1alghZo

Safari A., Suherman, and M Ali (2017) The Effect of Exercise Method and Hand-Eye Coordination Towards the Accuracy of Forehand Topspin in Table Tennis. 1st Annual Applied Science and Engineering Conference. IOP Publishing. doi:10.1088/1757-899X/180/1/012207

Sailer U, Flanagan JR, Johansson RS. (2005). Eye-hand coordination during learning of a novel visuomotor task. J Neurosci; 25

Schöborn R. (2000) Advanced techniques for competitive tennis. Oxford: Meyer\&Meyer Sport.

Singer R, Cauraugh J, Chen D, Steinberg G, Frehlich S. (1996) Visual search, anticipation, and reactive comparisons between highly-skilled and beginning tennis players. Journal Applied Sports Psych; 8:9-26. http://bit.ly/1HitlMr

Syahruddi (2016) The Effect Of Exercise Style Of Teaching And Command Styles Of Teaching To Over Passing Of Skills Volly ball. Jurnal Pedagogik Keolahragaan. 2 (1) $11-22$

Yani Mulyani dan Juliska Gracinia (2007) .Kemampuan Fisik, Seni dan Manajemen Diri. Jakarta: PT. Elex Media Kompentindo. 